This is an Accepted Manuscript of an article published by Taylor \& Francis in Spatial Economic Analysis online on $17 \mathrm{Feb} 2017$, available online:

http://www.tandfonline.com/10.1080/17421772.2017.1273542 


\title{
Agricultural rent in land use models: Comparison of frequently used proxies
}

\author{
Raja Chakir* and Anna Lungarska ${ }^{\dagger}$
}

December 6, 2016

\begin{abstract}
This paper compares the performance of econometric land use models based on three proxies for agricultural land rent: farmers' revenues, land prices, and shadow land prices derived from a mathematical programming model. We consider different land use classes (agriculture, pasture, forest, urban, and other), different determinants (economic, physical, and demographic) of land use shares, and different spatial econometric specifications. It is found that the inclusion of spatial components significantly improves the quality of predictions. In terms of economic interpretation, the shadow land prices provide the most stable and intuitive results.
\end{abstract}

Keywords: Land use share model, spatial dependence, land rent, prediction. JEL classifications:

*UMR Économie Publique, INRA, AgroParisTech, Université Paris-Saclay, 78850 Thiverval-Grignon, France. E-mail: raja.chakir@inra.fr.

†UMR Économie Publique, INRA, AgroParisTech, Université Paris-Saclay, 78850 Thiverval-Grignon, France. E-mail: Anna.Lungarska@inra.fr 


\section{Introduction}

Land use and land use change (LUC) are among the main human pressures on the environment (Foley et al., 2005). Some LUCs e.g. deforestation, could have adverse effects on the environment such as reduced biodiversity (Sala et al., 2000), carbon release into the atmosphere (Rhemtulla, Mladenoff and Clayton, 2009), changes to water cycles (Stevenson and Sabater, 2010) and loss of ecosystem services (Schröter et al., 2005). Other LUCs such as the establishment of permanent grassland or afforestation, could store carbon in the soil, and thus, contribute to reducing greenhouse gas emissions and preserving the environment. Developing precise LUC models could be useful to provide policy makers with insights into future LUCs driven by global change. Also these models could be used to evaluate policy mechanisms designed to reduce the negative environmental externalities of LUCs (greenhouse gas emissions, loss of biodiversity, reduced water quality, etc.).

Econometric land use models focus mainly on the behavioral decisions of landowners who choose among land uses in order to maximize the benefits from their land. The emerging decision rule states that optimal land use is determined by comparing the rents associated with each possible land use net of conversion costs. According to economic theory, land rents vary depending on land characteristics such as fertility (Ricardo, 1817) and location (von Thünen, 1826). However, there are other factors that can affect the land use decision for a given plot. These include socio-economic factors such as production prices, and policy variables such as taxes or subsidies. Econometric studies of land use generally examine the relationship between land use choices and a set of explanatory variables, namely the rents derived from different land uses, or proxies such as input and output prices, subsidies, and soil and climatic variables (slope, altitude, soil quality, temperature, precipitation, etc.). Land rent is a rather complex notion and the literature proposes several concepts of economic rent. ${ }^{1}$

Usually, land use rents are not directly observed, and most studies approximate them using other variables. These proxies for land use rents vary across studies but the most frequently used proxies for agriculture include producer's revenue, agricultural land price, output or input prices, yield, land quality, and government payments (e.g.

\footnotetext{
${ }^{1}$ See Randall and Castle (1985) for a detailed presentation on the concept of land rent.
} 
Wu and Segerson, 1995; Plantinga, 1996; Stavins and Jaffe, 1990; Plantinga and Ahn, 2002). The objective of the present paper is to compare land use models based on three different proxies for agricultural land rent: (i) farmer's revenue, (ii) land price, and (iii) the shadow price of land derived from a mathematical programming model (AROPAj, Jayet et al., 2015). Farmer's revenue is the most frequent economic variable in land use literature (Stavins and Jaffe, 1990; Plantinga and Ahn, 2002; Lubowski, Plantinga and Stavins, 2008; Chakir and Le Gallo, 2013). Data on revenues from agriculture can be derived from agricultural censuses or surveys. The second proxy, land price, generally is considered equal to the net present value (NPV) of future land rents (Ricardo, 1817). It is often used in the context of climate change impact assessments, otherwise known as the Ricardian method proposed initially by Mendelsohn, Nordhaus and Shaw (1994) and which focuses solely on agricultural use. In the land use literature, Ay, Chakir, Doyen, Jiguet and Leadley (2014) use the agricultural land price to approximate land rents in an econometric land use model to study the impacts of climate change on land use in France.

Our third proxy, the land shadow price, to the best of our knowledge, has not so far been used in econometric land use share models. Using the land shadow price to proxy for agricultural land rent is one of the main contributions of our paper. The shadow price corresponds to the marginal productivity of the land estimated using a European Union mathematical programming model for agriculture. ${ }^{2}$ Generally, shadow prices are used when no market valuation is available. In the case of France, the agricultural land market is regulated by public structures, and land prices and land rents are upper bounded (Dupraz and Temesgen, 2012). Thus, estimated shadow prices sometimes provide more relevant insight into agricultural land productivity. Another argument in favor of land shadow price is that these figures are not influenced by conversion option values (such as development options) which increase land prices for reasons unrelated to agriculture. Compared to agricultural revenues, land shadow prices are obtained for perfectly informed farmers, and as such, correspond to the farmers expected revenues under no price or climate hazards.

In order to compare the impacts of these different agricultural rent proxies, we estimate

\footnotetext{
${ }^{2}$ The economic supply-side model AROPAj (for detailed description see Jayet et al., 2015) is based on the Farm Accountancy Data Network (FADN).
} 
land use share models at a homogeneous $8 \mathrm{~km} \times 8 \mathrm{~km}$ cell grid resolution, to cover the territory of metropolitan France. We consider five land use classes: agriculture, pasture, forestry, urban, and other. Land use data are derived from the remote sensing database, Corine Land Cover $\left(\mathrm{CLC}^{3}\right)$. We model spatial dependence between grid cells, and compare different spatial model specifications.

Although work in the land use literature which take explicit account of spatial dependence has increased according to Brady and Irwin (2011), still, only a few studies apply spatial econometric tools (Ay, Chakir and Le Gallo, 2016; Chakir and Le Gallo, 2013; Li, Wu and Deng, 2013; Sidharthan and Bhat, 2012; Ferdous and Bhat, 2013; Chakir and Parent, 2009). Most recent econometric land use models proposed by articles published in high quality journals tend to ignore spatial dependence, or use ad hoc methods ${ }^{4}$ to deal with it (e.g. Irwin, Bell and Geoghegan, 2003; Carrion-Flores and Irwin, 2004; Lubowski et al., 2008; Fezzi and Bateman, 2011). This is because spatial dependence raises several issues related to econometric estimation, hypothesis testing, and prediction - especially in the case of discrete choice models (Anselin, 2007; Brady and Irwin, 2011).

According to Gibbons and Overman (2012) and Corrado and Fingleton (2012), most papers in the field of applied spatial econometrics focus on choosing the best model specification and conduct batteries of tests to justify that choice, at the expense of considering the crucial issue of identifying the causal effects. Causality is central in our paper, and our empirical question is based on economic theory which states that land use is determined by the land rent (Lichtenberg, 1989; Lubowski et al., 2008). The idea here is to test different definitions of agricultural land rent since this concept is rather vague and difficult to define empirically (Hardie, Parks, Gottleib and Wear, 2000). In the present paper, we focus on three possible definitions of agricultural land rent: agricultural land price, farm income, and the land shadow price and compare different spatial specifications of the econometric model using the three rent proxies. These comparisons are made based on various criteria including: consistency with the theoretical hypothesis (significance of agricultural rents and their marginal impacts), prediction quality (NRMSE - normalized

\footnotetext{
${ }^{3}$ For more information on CLC: http://land.copernicus.eu/pan-european/corine-land-cover .

${ }^{4}$ De Pinto and Nelson (2007) enumerate three types of ad hoc corrections for spatial effects which are available in the land-use literature: spatial sampling, latitude and longitude as exogenous variables, and spatially lagged geophysical variables.
} 
root-mean-square error) and specification tests (LM - Lagrange multiplier - tests).

Our study is organized as follows. In section 2 we present the land use share model specification employed, discuss some implications of the spatial dependence, and describe the most frequently used specifications for spatial models. The data used in our study are provided in section 3 and the results obtained using the three proxies and the different model specification are presented in section 4 . The paper concludes in section 5 .

\section{The Model}

\subsection{Land use share model}

In this section we describe our land use share model. This type of model specification is standard in the literature (Lichtenberg, 1989; Stavins and Jaffe, 1990; Wu and Segerson, 1995; Plantinga, 1996; Miller and Plantinga, 1999). The model starting point is the assumption that landowners derive the optimal land allocation from their profitmaximization problem. Here, we focus on the landowner's decision to allocate land among five possible uses: agriculture, pasture, forest, urban, and other. Landowners allocate land to the use providing the greatest NPV of their profits (Plantinga, 1996; Stavins and Jaffe, 1990). The optimal allocations of individual landowners are aggregated in order to derive the observed share of land in the grid cell $i$ in use $k$, denoted $y_{k i}$.

Following recent studies by Ay et al. (2016) and Chakir and Le Gallo (2013), we specify an aggregated land use share model. Our study is conducted at grid-level where shares are defined as percentages of the total grid area devoted to given uses. The observed share of land use $k(k=1, \ldots, K)$ in grid cell $i(i=1, \ldots, I)$ is expressed as:

$$
y_{k i}=p_{k i}+u_{k i} \quad \forall i=1, \ldots, I, \quad \forall k=1, \ldots, K,
$$

where $p_{k i}$ is the expected share of land allocated to use $k$ in grid cell $i$. The estimated optimal allocation may be different from the observed allocation $y_{k i}$ because of the effects of random factors such as bad weather or unanticipated price changes. These random events are assumed to have zero mean.

As in Wu and Segerson (1995) and Plantinga, Mauldin and Miller (1999), we use a 
$\operatorname{logistic}^{5}$ specification for the share functions as follows:

$$
p_{k i}=\frac{e^{\beta_{k}^{\prime} X_{i}}}{\sum_{j=1}^{K} e^{\beta_{j}^{\prime} X_{i}}}
$$

where $X_{i}$ are explanatory variables and $\beta_{k}^{\prime}$ measure the effect of the explanatory variables on the expected shares.

Following Zellner and Lee (1965), the natural logarithm of each observed share normalized on a common share (here $y_{K i}$ ) is equal to approximately:

$$
\widetilde{y}_{k i}=\ln \left(y_{k i} / y_{K i}\right)=\beta_{k}^{\prime} X_{i}+\varepsilon_{k i} \text { for } \forall i=1, \ldots, I, \quad \forall, k=1, \ldots, K,
$$

where $\varepsilon_{k i}$ is the transformed error term. The model in equation 3 is identified if we constrain $\beta_{K}=0$.

\subsection{Spatial dependence}

Spatial autocorrelation and dependence could result in aggregated land use share models from a structural spatial relationship among the values of the dependent variable (SAR spatial auto-regressive model), or a spatial autocorrelation among the error terms (SEM spatial error model). The former is regarded as a fundamental characteristic of the spatial processes characterized by potentially complex interactions, and dependent structures among neighboring values. Spatial autocorrelation due to a spatially correlated error term is essentially a data measurement problem. For instance, it can emerge from data measurement errors involving the spatial limits of the phenomena which differ from the boundaries used for the measurement. Spatially correlated omitted variables ${ }^{6}$ are another possible source of spatial autocorrelation. This applies to our data where use of artificially constructed grids and differing scales could explain the existence of spatial autocorrelation (Anselin, 1988).

Omitting spatial dependence from a spatial data generating process could adversely

\footnotetext{
${ }^{5}$ Logistic share models are preferred for three main reasons: (i) they ensure that the predicted share functions lie (strictly) in the interior of the zero-one interval, (ii) they are parsimonious in their parameters, and (iii) they are empirically tractable thanks to the so-called log-linear transformation.

${ }^{6}$ See the paper by LeSage and Pace (2009) which provides motivations for regression models that include spatial autoregressive processes.
} 
affect the land use model. It could suffer from bias in the regression coefficients, inconsistency, inefficiency, masking effects of spillovers, and prediction bias. There are several procedures that can be used to test statistically for the presence of spatial dependence against the null hypothesis of spatial independence (Anselin, 1988). The most commonly used measure of spatial autocorrelation is Moran's (1948) I statistic which indicates the degree of spatial association reflected in the data. Consideration of spatial dependence in an econometric model can be achieved in various ways by including spatially lagged variables, i.e., weighted averages of observations of the "neighbors" of a given observation (Anselin, 1988). These spatially lagged variables can be the dependent variable (SAR), explanatory variables (spatial cross regressive model, SLX), or the error terms (SEM), or any combination of these options which results in a range of spatial models (Elhorst, 2010). For instance, the spatial autoregressive confused model (SAC) accounts simultaneously for autocorrelation in the error term and for spatial associations of the dependent variable. The spatial Durbin model (SDM) combines the SAR and the SLX models while the spatial Durbin error model (SDEM) integrates all the elements of the SLX and the SEM. Finally, the general nesting spatial model (GNS) combines the SAC and the SLX.

We consider in this paper spatial models labeled SAR, SEM, SLX, SDM, SDEM, SAC, and GNS in Anselin (1988); LeSage and Pace (2009) and Elhorst (2014). Table 1 summarizes the different estimated spatial model specifications and their interpretation. We then compare different spatial specifications of the econometric model using the three rent proxies. These comparisons are based on several criteria: quality of economic explanation (significance of agricultural rents and their marginal impacts), prediction quality (NRMSE), and specification tests (LM tests).

The spatial neighborhood matrix, $W$, is obtained following the queen contiguity rule of grid cell borders, and consequentially, its values are row-weighted. ${ }^{7}$

\footnotetext{
${ }^{7}$ For our estimations of the different spatial specifications, we use the R package spdep (Bivand, Hauke and Kossowski, 2013; Bivand and Piras, 2015).
} 


\begin{tabular}{|c|c|c|}
\hline Model & Model presentation & Interpretation \\
\hline SEM & $\begin{array}{l}\widetilde{y}=X \beta+\varepsilon \\
\varepsilon=\lambda W \varepsilon+u\end{array}$ & $\begin{array}{l}\text { Unobserved omitted variables follow } \\
\text { a spatial pattern, data measurement errors }\end{array}$ \\
\hline SAR & $\widetilde{y}=\rho W \widetilde{y}+X \beta+\varepsilon$ & $\begin{array}{l}\text { Land use share for one location is determined } \\
\text { jointly with that of neighboring locations. }\end{array}$ \\
\hline SLX & $\widetilde{y}=X \beta+W X \gamma+\varepsilon$ & $\begin{array}{l}\text { Land use share for one location is determined by } \\
\text { the explanatory variables of neighboring locations. }\end{array}$ \\
\hline $\mathrm{SDM}$ & $\widetilde{y}=\rho W \widetilde{y}+X \beta+W X \gamma+\varepsilon$ & A combination of SLX and SAR \\
\hline SAC & $\begin{array}{l}\widetilde{y}=\rho W \widetilde{y}+X \beta+\varepsilon \\
\varepsilon=\lambda W \varepsilon+u\end{array}$ & A combination of SEM and SAR \\
\hline SDEM & $\begin{array}{l}\widetilde{y}=X \beta+W X \gamma+\varepsilon \\
\varepsilon=\lambda W \varepsilon+u\end{array}$ & A combination of SEM and SLX \\
\hline GNS & $\begin{array}{l}\widetilde{y}=\rho W \widetilde{y}+X \beta+W X \gamma+\varepsilon \\
\varepsilon=\lambda W \varepsilon+u\end{array}$ & A combination of SLX and SAC \\
\hline
\end{tabular}

Table 1: Summary table of the estimated spatial model specifications

\section{Data presentation}

\subsection{Land use data}

The land use data are from the CLC database for France at the scale of $100 \mathrm{~m} \times 100 \mathrm{~m}$ $\left(1 \mathrm{ha}^{8}\right)$ grids for the year 2000. The land cover classes considered in this paper are agriculture, pasture, forest, urban, and other. Table A1 in appendix A summarizes the rules applied for the land use classification which are depicted in figure 1. We can then calculate the share of each land use class for each $(8 \mathrm{~km} \times 8 \mathrm{~km})$ grid cell; we know that each cell includes a maximum of 6,400ha. Land use shares are expressed as the sum of the same land use classes in hectares divided by the surface of the grid cell. Although these cells are generated to be homogeneous, they are changed by their intersection with the French borders. For instance, grid cells on the coast are restricted to their parts on dry land.

\subsection{Proxies for agricultural and forestry rents}

General information and descriptive statistics for the variables used in the study are summarized in table 2 .

\footnotetext{
${ }^{8}$ Areal phenomena's minimal mapping unit is of 25 ha and for linear phenomena the scale is 1 ha.
} 


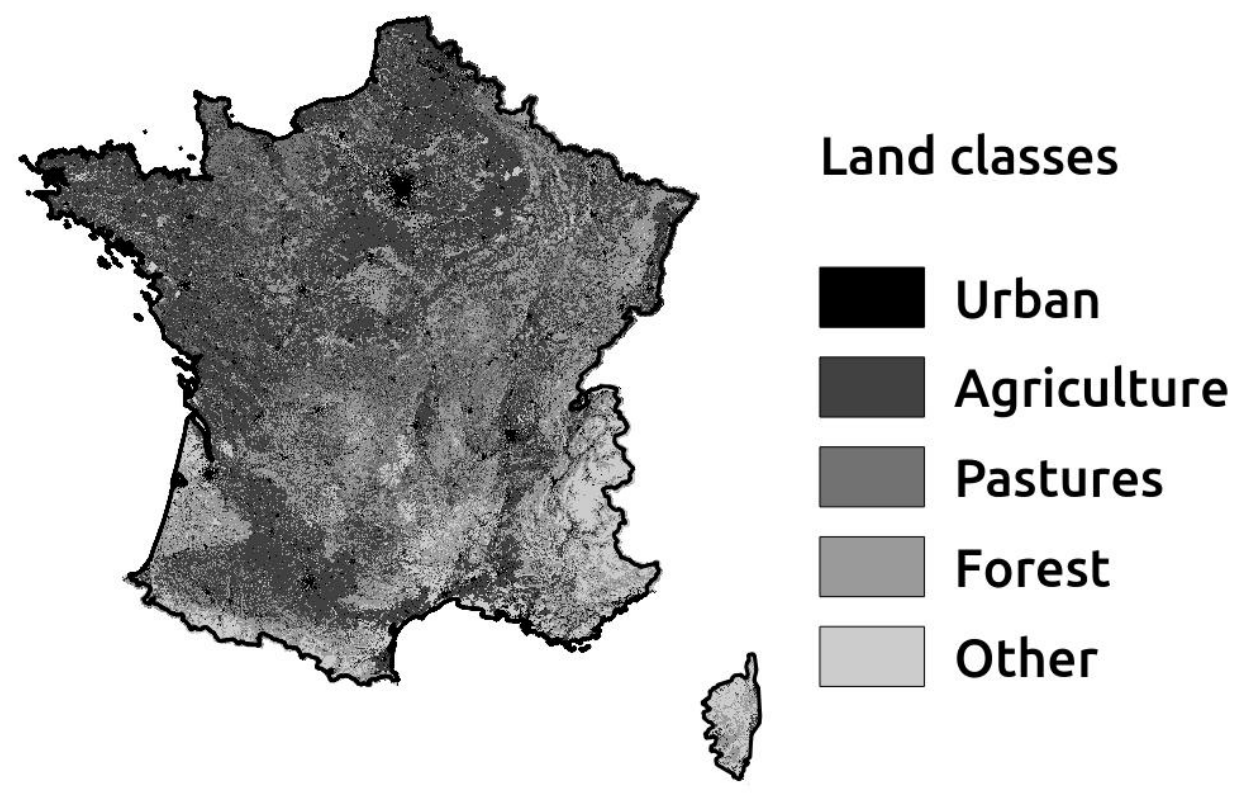

Figure 1: Corine Land Cover (CLC) data aggregated in five land use classes for the year 2000

Farmers' revenues Data on farmers' revenues are from the European Union Farm Accountancy Data network (FADN) at the European NUTS 2 level (Gross Farm Income variable, SE410). We focus on the revenues from crop production (cereals, oleaginous and other field crops) and animal breeding. Revenues from viticulture, horticulture, and other perennial crops are excluded because of the high profits per hectare and their limited areas (table A2 in appendix A). For instance, viticulture in France accounts for only $1.5 \%$ of the metropolitan territory but provides about $15 \%$ of agricultural sector value. ${ }^{9}$

Land price As already mentioned in the introduction, land prices generally are assumed to be the NPV of future land rents (Ricardo, 1817). Frequently, land prices are used in the context of a hedonic approach to climate change impact assessments, otherwise known as the Ricardian method proposed initially by Mendelsohn et al. (1994) which focuses solely on agricultural use. Because of the influence of urbanization on agricultural land prices, Schlenker, Michael Hanemann and Fisher (2005) account for population density in their analysis of climate change effects on U.S. agriculture. The standard NPV formula ignores the possibility of land conversion to other than agricultural use (Clark, Fulton and Scott, 1993; Gutierrez, Westerlund and Erickson, 2007; Karlsson and Nilsson, 2013)

\footnotetext{
${ }^{9}$ FranceAgriMer, www.franceagrimer.fr.
} 
which might be a rather strong assumption. To address this, Guiling, Brorsen and Doye (2009) extend the NPV formula. The most profitable conversion is to land development (switch to urban use). In the case of France, Cavailhès and Wavresky (2003) find that immediate proximity to a city results in a high development premium which falls sharply as the distance from the city increases. In the land use literature, Ay et al. (2014) use the Ricardian approach to assess the effects of climate change on land use, and consequently, common birds in France. The annual data on land prices used in our paper, are provided by the statistical department of the French Ministry of Agriculture (Agreste) at the scale of a French small agricultural region or a group of regions. ${ }^{10}$

Land shadow price In this study, we test land shadow price used as a proxy; to our knowledge, this is the first such application in econometric land use share models. The shadow price captures the non-market value that farmers attribute to their production, and accounts for the complex interactions between on-farm activities. We use the values estimated by a European Union mathematical programming model for agriculture, and apply them to France. The economic supply-side model AROPAj (for a detailed description see Jayet et al., 2015) is based on FADN data and accounts for the Common Agricultural Policy. The economic agents in the model are representative farms grouped by farm types maximizing their gross margins (revenues minus variable costs). For each farmer the only publicly available information concerning location is the FADN region in which he/she operates. In order to maximize their profits, in the model farmers allocate their land to different crops while respecting a total area constraint. We use the LM associated with this constraint in our comparative study of agricultural returns proxies. Microeconomic theory tells us that at the optimum, this LM (shadow price or dual value) should be equal to the annual agricultural rent. ${ }^{11}$

Shadow prices are used when real market values are not available, or when existing ones do not include some particularity of the good in question. In the case of France, land

\footnotetext{
${ }^{10} \mathrm{~A}$ small agricultural region is a French territorial division and is a subdivision of the administrative regions. Their territory varies from some 1,000ha to more than 400,000ha.

${ }^{11}$ Agricultural rent is the remuneration of land as a factor of production. The equality between the LM associated with the total land constraint and the agricultural rent results from application of the duality theorem to the profit maximization problem. Following this approach the profit maximization problem is equivalent to the cost minimization problem. For a general description see McFadden (1978).
} 
rental prices are administered by public authorities, ${ }^{12}$ and thus, the shadow price and the observed rental prices do not coincide (Dupraz and Temesgen, 2012). Furthermore, agriculture is a complex system where some products are consumed on-farm, ${ }^{13}$ and thus, are not valued on the market. As land prices and rents are upper bounded, they potentially can underestimate the profits associated with land.

Data on the agricultural rent proxies are available at different scales and for different years. Some aggregation was necessary in order to obtain data on the same scale. Thus, farmers' revenues and land prices are averaged over period of respectively five and six years. ${ }^{14}$ In the absence of information on land prices for a given small agricultural region, we use the mean value for the corresponding French département. The data on land shadow prices from the AROPAj model are considered at their original scale, namely the FADN region (corresponding to the NUTS 2 level).

Forestry rents are approximated by expected returns estimated by the partial-equilibrium model FFSM ++ (Caurla and Delacote, 2012; Caurla, Delacote, Lecocq, Barthès and Barkaoui, 2013; Lobianco, Delacote, Caurla and Barkaoui, 2015) developed by the Forestry Economics Laboratory at the French Agricultural Research Institute (INRA) in Nancy. The expected returns are calculated annually starting in 2006, at the scale of the French administrative region (NUTS2). The revenue is for coniferous and broadleaved forests, and accounts for the potential switching between these two forest types under a constant forest area hypothesis (for more information, see Lobianco, Delacote, Caurla and Barkaoui, 2016).

Both the AROPAj and the FFSM ++ models include biological modules. AROPAj is partly coupled with the generic crop model STICS (Brisson et al., 2003; Brisson, Launay, Mary and Beaudoin, 2009), while FFSM ++ uses parameters (tree mortality and growth) derived from statistical data. Their biological modules allow both models to account

\footnotetext{
${ }^{12}$ French Rural Code, Article L411-11. In some regions this regulation is circumvented and new tenants are often obliged to pay under-the-counter former ones in order to obtain rights on land.

${ }^{13}$ For instance, manure could be used as a fertilizer on crops while some biomass produced could be destined for animal feeding.

${ }^{14}$ Inflation estimates for the period were obtained from the World Bank, http://data.worldbank. org/indicator/NY.GDP.DEFL. KD.ZG.
} 
for the effects of climate change (in the case of AROPAj the linkage between modules is detailed in Leclère, Jayet and de Noblet-Ducoudré, 2013). Also, the economic components of the models allow simulation of different price and policy scenarios. ${ }^{15}$

\subsection{Demography}

In this paper we follow Haim, Alig, Plantinga and Sohngen (2011) and use two proxies for urban rent: population density, and household revenue. Both indicators are provided by the French statistical institute (INSEE) and available at the French commune scale. The justification for using population density to proxy for urban returns is that the pressures to develop land, and thus, the rents for urban land, are higher in more densely populated locations. Population density is commonly used in the land use literature to proxy for urban rent. Most studies using this proxy highlight its limitations, especially the fact that potentially it is endogenous.

\subsection{Physical data}

We use data on land topography.

Soils are represented by the data provided by the Joint Research Centre (JRC) (Panagos, Van Liedekerke, Jones and Montanarella, 2012) at the scale of 1:1000000 and further aggregated at grid cell level. The indicator we use for soil quality is soil texture according to four levels. The lowest quality, level 1, is used as the reference. Land quality is an important variable in land use models (Chakir and Le Gallo, 2013; Ahn, Plantinga and Alig, 2000; Lubowski et al., 2008).

Relief (altitude and slope) is derived from the digital elevation model GTOPO, available at the scale of 30 arc seconds (approximately $1 \mathrm{~km}$ ). In the model we only introduce slope because of the high correlation between slope and altitude. Also, slope leads to better results in terms of the model fit.

Because of the strong correlations between the different climatic and edaphic variables

\footnotetext{
${ }^{15}$ For instance, an obligatory set-aside clause increases demand for low quality land and consequently its rent.
} 
we perform principal component analysis (PCA) and multiple correspondence analysis (MCA) in order to determine the main axes of variation and retain composite indicators for the physical parameters. Based on the results of our analysis we decided to retain only the two variables described above which were identified as being the most influential.

\begin{tabular}{|c|c|c|c|c|c|}
\hline Variable & Description & Mean & St. dev. & Min & Max \\
\hline \multicolumn{6}{|l|}{ Land use } \\
\hline$s_{a g}$ & Share of agricultural use & 0.438 & 0.276 & 0 & 1 \\
\hline$s_{p a}$ & Share of pastures & 0.181 & 0.181 & 0 & 0.94 \\
\hline$s_{f o}$ & Share of forests & 0.262 & 0.22 & 0 & 0.989 \\
\hline$s_{u r}$ & Share of urban & 0.053 & 0.097 & 0 & 0.99 \\
\hline \multirow[t]{3}{*}{$s_{o t}$} & Share of other uses & 0.065 & 0.133 & 0 & 1 \\
\hline & Source: CLC 2000 & & & & \\
\hline & Scale: aggregated at $8 \mathrm{~km} \times 8 \mathrm{~km}$ & & & & \\
\hline \multirow[t]{3}{*}{ Shadow price } & Land shadow price $(\mathrm{k} € / \mathrm{ha})$ & 0.576 & 0.197 & 0 & 1.029 \\
\hline & Source: AROPAj v.2 (2002) & & & & \\
\hline & Scale: NUTS 2 scale & & & & \\
\hline \multirow[t]{3}{*}{ Farmers' revenues } & Farmers' revenues $(\mathrm{k} € / \mathrm{ha})$ & 0.651 & 0.153 & 0.19 & 0.975 \\
\hline & Source: FADN, mean 1995-1999 & & & & \\
\hline & Scale: NUTS 2 scale & & & & \\
\hline \multirow[t]{3}{*}{ Land price } & Price for arable land $(\mathrm{k} € / \mathrm{ha})$ & 3.035 & 1.485 & 0 & 20.256 \\
\hline & Source: Agreste, mean 1995-2000 & & & & \\
\hline & $\begin{array}{l}\text { Scale: French small agricultural re- } \\
\text { gion or département }\end{array}$ & & & & \\
\hline \multirow[t]{3}{*}{ For revenue } & Forestry revenues $(€ /$ ha $)$ & 137.20 & 65.54 & 28.93 & 308.00 \\
\hline & Source: FFSM++, results for 2006 & & & & \\
\hline & Scale: NUTS 2 scale & & & & \\
\hline \multirow[t]{4}{*}{ Pop revenues } & Households' revenues & 12.424 & 3.213 & 0 & 44.642 \\
\hline & (k€/ year/ household) & & & & \\
\hline & Source: INSEE, 2000 & & & & \\
\hline & Scale: French commune & & & & \\
\hline \multirow[t]{3}{*}{ Pop density } & Population density & 5.541 & 2.973 & 2.75 & 140.131 \\
\hline & Source: INSEE, 1999 & & & & \\
\hline & Scale: French commune & & & & \\
\hline \multirow[t]{3}{*}{ Slope } & Slope $(\%)$ & 4.363 & 6.211 & 0 & 44.2 \\
\hline & Source: GTOPO 30 & & & & \\
\hline & Scale: $30 \operatorname{arc~sec}(\sim 1 \mathrm{~km})$ & & & & \\
\hline \multirow[t]{4}{*}{ TEXT } & Soils' texture classes & 1 & 2 & 3 & 4 \\
\hline & Number of cells & 1179 & 4256 & 2858 & 525 \\
\hline & Source: JRC, Panagos et al. (2012) & & & & \\
\hline & Scale: $1: 1,000,000$ & & & & \\
\hline
\end{tabular}

Table 2: Summary statistics of land use shares and the explanatory variables 


\section{Estimation results}

In order to compare estimations and evaluate the gains associated with different spatial specifications, we consider OLS, SLX, SEM, SAR, SDM, SDEM, SAC, and GNS estimators for each land use share model. ${ }^{16}$ Each specification is estimated for the three proxies for agricultural land rents - shadow price, farmer's revenue, and arable land prices. The estimated coefficients and other results are presented in the supplementary materials (appendix D).

Models with different spatial specifications (SLX, SEM, SAR, SDM, SDEM, SAC, GNS) and different agricultural land rents proxies are estimated, and LM and Hausman tests are run to compare these specifications. We then compare models according to three criteria: goodness of fit (log-likelihood, AIC and R-squared), quality of prediction (NRMSE), and economic interpretation of marginal agricultural land rent effects (elasticities).

\subsection{Specification tests}

For all OLS models the Moran's $I$ score $^{17}$ is significant meaning that the null hypothesis of no spatial autocorrelation is rejected for the three proxies for agricultural land rents. There are numerous possible sources of autocorrelation in our dataset. For instance, we might be introducing artificial spatial autocorrelation by replicating the regional values of the agricultural and forestry rents to each of the regular grid cells. In order to verify if this is the case, we estimate the land use models excluding agricultural and forestry rents and run Moran's I test on the results for the linear specification. The resulting statistics remain highly significant, and the values of Moran's I are close to those obtained previously. Thus, we can conclude that the spatial autocorrelation in our dataset is due mostly to factors other than changes to the scale of the explanatory variables. Another possible source of autocorrelation are the physical parameters (slope and soil texture) since they are subject to geological processes at a scale which does not coincide with the

\footnotetext{
${ }^{16}$ We do not directly account for inter-equation correlation. However, as shown in Chakir and Le Gallo (2013), since the same explanatory variables are used in each equation, we do not expect this to affect our results significantly.

${ }^{17}$ Actual values of the test are provided in the suplementary materials (appendix D), tables D2, D10, and D18.
} 
regular grid used in the study.

We use the Hausman test proposed by LeSage and Pace (2009) to test the equality of the coefficient estimates from OLS and SEM. This test is a good indication of specification problems (such as omitted variables correlated with the explanatory variables) not present in the SEM. Our results for this test show that we reject the null hypothesis of equality of the SEM and OLS estimates (table 3). According to LeSage and Pace (2009) this means that the omitted variables represent a serious problem, or are correlated with the explanatory variables. Consequently, we cannot conclude that SEM is the best specification since the Hausman test indicates that this model is misspecified. Other spatial specifications need to be considered.

To compare different spatial model specifications (OLS, SLX, SEM, SAR, SDM, SDEM, SAC, and GNS) we use the classic LM test proposed by Anselin (1988) and the robust LM test proposed by Anselin, Bera, Florax and Yoon (1996). Table 4 presents the results of these tests. Using the classic tests, both hypotheses of no spatially lagged dependent variable and no spatially autocorrelated error term are rejected at $1 \%$ significance for all models. The robust LM test results show that both SAR and SEM specifications are relevant for $\ln ($ pst/oth $)$ and $\ln ($ agr/oth $) .{ }^{18}$ This means that the SAC or SDM specifications can be considered. The results of the SLX and SDM models show that we should consider the GNS specification.

\begin{tabular}{lcccc}
\hline Proxy & $\ln ($ pst $/$ oth $)$ & $\ln ($ agr $/$ oth $)$ & $\ln ($ for $/$ oth $)$ & $\ln ($ urb $/$ oth $)$ \\
\hline Regional dual & & & & \\
& 312.7065 & 325.6753 & 287.0825 & 106.8259 \\
& $<2.2 \mathrm{e}-16$ & $<2.2 \mathrm{e}-16$ & $<2.2 \mathrm{e}-16$ & $<2.2 \mathrm{e}-16$ \\
Land prices & & & & \\
& 315.5557 & 333.4682 & 289.641 & 115.9688 \\
& $<2.2 \mathrm{e}-16$ & $<2.2 \mathrm{e}-16$ & $<2.2 \mathrm{e}-16$ & $<2.2 \mathrm{e}-16$ \\
Farmers' revenue & & & & \\
& 303.3948 & 330.8311 & 294.3477 & 113.4367 \\
& $<2.2 \mathrm{e}-16$ & $<2.2 \mathrm{e}-16$ & $<2.2 \mathrm{e}-16$ & $<2.2 \mathrm{e}-16$ \\
\hline
\end{tabular}

Table 3: Hausman test for the difference between the OLS and the SEM estimates

All the estimated coefficients for spatial autocorrelation, $\lambda$ for the SEM and SDEM,

\footnotetext{
${ }^{18}$ The complete results of the tests are provided in tables D44 and D45 in the supplementary materials (appendix D).
} 
Agricultural land rent proxy

Farmers'

Test

Shadow Price

Land Price

Revenues

OLS vs. $\operatorname{SEM}\left(\mathbf{H}_{0}: \lambda=0\right)$

$\begin{array}{lrrr}\text { LM error } & 6539.94^{* * *} & 6541.02^{* * *} & 6537.24^{* * *} \\ \text { Robust LM error } & 388.54^{* * *} & 386.85^{* * *} & 387.84^{* * *}\end{array}$

OLS vs. SAR $\left(\mathbf{H}_{0}: \rho=0\right)$

$\begin{array}{lrrr}\text { LM lag } & 6326.48^{* * *} & 6334.06^{* * *} & 6327.88^{* * *} \\ \text { Robust LM lag } & 175.08^{* * *} & 179.9^{* * *} & 178.47^{* * *}\end{array}$

OLS vs. $\mathbf{S A C}\left(\mathbf{H}_{0}: \lambda=\rho=0\right)$

LM lag + error $\quad 6715.02^{* * *} \quad 6720.92^{* * *} \quad 6715.72^{* * *}$

SLX vs. $\operatorname{SDEM}\left(\mathbf{H}_{0}: \lambda=0\right)$

$\begin{array}{lrrr}\text { LM error } & 6632.2^{* * *} & 6608.43^{* * *} & 6626.52^{* * * *} \\ \text { Robust LM error } & 8.68^{* * *} & 3.2^{* * *} & 7.59^{* * *}\end{array}$

SLX vs. $\mathbf{S D M}\left(\mathbf{H}_{0}: \rho=0\right)$

$\begin{array}{lrrr}\text { LM lag } & 6651.46^{* * *} & 6648.84^{* * *} & 6649.84^{* * *} \\ \text { Robust LM lag } & 27.94^{* * *} & 43.61^{* * *} & 30.92^{* * *}\end{array}$

SLX vs. GNS $\left(\mathbf{H}_{0}: \lambda=\rho=0\right)$

LM lag + error $\quad 6660.14^{* * *} \quad 6652.04^{* * *} \quad 6657.44^{* * *}$

SAR vs. $\mathbf{S A C}\left(\mathbf{H}_{0}: \lambda=0\right)$

$\begin{array}{llll}\text { LM error } & 7.4987^{* * *} & 7.6944^{* * *} & 7.6126\end{array}$

SDM vs. GNS $\left(\mathbf{H}_{0}: \lambda=0\right)$

$\begin{array}{llll}\text { LM error } & 17.8209^{* * *} & 18.3835^{* * *} & 18.0562\end{array}$

Table 4: Results for the spatial autocorrelation tests for the agricultural land use models 
and spatial autoregressive coefficient $\rho$ for the SAR and SDM, are significant at $1 \% .{ }^{19}$ In the case of the SAC, $\lambda$ is significant only in the urban land use equation while $\rho$ is significant in the other three equations. For the GNS with shadow prices and land prices, $\rho$ is significant only in the urban model while $\lambda$ is significant elsewhere. If we use farmers' revenues, $\lambda$ is significant for the pastures and agriculture models and $\rho$ is significant for the other two models. In our results, these two spatial coefficients are never significant simultaneously. The spatially lagged variables in the SLX are improving the $R^{2}$ scores somewhat (compared with the OLS specification). Under this specification and for the agricultural land models, the coefficients associated with texture are all significant and the signs for the variable and its spatially lagged values are both positive. The significant negative impact of slope is valid also for the lagged slope variable, and for population density.

Population density and household revenue are significant and have the expected positive signs for the urban model regardless of the agricultural rent proxy employed and the model specification. However, in the SLX and the SDEM, the lagged variable of density is not significant, and in the SDM the lagged values have a negative impact. The density variables in the GNS models have the same coefficients but with opposing signs (the coefficient of lagged value is negative). This could be the result of the multicollinearity introduced through the lagged variables.

\subsection{Goodness of fit}

Table 5 summarizes the results for goodness of fit for the different models. These results show that compared to the OLS specification, log-likelihood (LL) function and AIC are improved for all the spatial specifications except the SLX. For land shadow price these criteria go from $L L_{O L S}=-22363$ and $A I C_{O L S}=44745$ to $L L_{G N S}=-20251$ and $A I C_{G N S}=$ 40542. This result is valid for the three agricultural rent proxies which means that the choice of the best spatial specification is independent of the rent proxy used.

Although there is no equivalent of the R-squared for spatial models, to assess the goodness of fit of alternative spatial model specifications, we provide a pseudo R-squared

\footnotetext{
${ }^{19}$ Full details on estimates are provided in tables D2-D25 in the supplementary materials.
} 
metric based on Nagelkerke (1991). In the OLS specification, the agricultural vs. other use and the urban vs. other use models perform better in terms of explained variance, with $R^{2}$ close or superior to $40 \%{ }^{20}$ The other two models, forest vs. other use and pasture vs. other use, do not score as high; the $R^{2}$ coefficients of pasture are lower than $30 \%$ and the same coefficient of forest are close to $15 \%$. When spatial component is introduced the $R^{2}$ mostly (except the SLX) improve greatly from $R_{O L S}^{2}=0.425$ to $R_{G N S}^{2}=0.644$. In the case of agricultural land use, and according to the pseudo-R-squared criteria, the best specification is the GNS model regardless of the agricultural rent proxy used.

\begin{tabular}{lrrrrrrrrr}
\hline & \multicolumn{3}{c}{ Shadow price } & \multicolumn{3}{c}{ Land price } & \multicolumn{3}{c}{ Farmers' Revenues } \\
\cline { 2 - 10 } Model & $R^{2}$ & LL & AIC & $R^{2}$ & LL & AIC & $R^{2}$ & LL & AIC \\
\hline OLS & 0.425 & -22363 & 44745 & 0.424 & -22367 & 44753 & 0.424 & -22366 & 44751 \\
SEM & 0.635 & -20356 & 40734 & 0.635 & -20357 & 40736 & 0.635 & -20358 & 40737 \\
SAR & 0.638 & -20322 & 40666 & 0.638 & -20321 & 40665 & 0.638 & -20321 & 40665 \\
SDM & 0.64 & -20290 & 40618 & 0.641 & -20288 & 40614 & 0.64 & -20290 & 40619 \\
SAC & 0.639 & -20311 & 40645 & 0.639 & -20310 & 40643 & 0.639 & -20310 & 40644 \\
SLX & 0.439 & -22254 & 44544 & 0.439 & -22252 & 44539 & 0.439 & -22255 & 44546 \\
SDEM & 0.641 & -20289 & 40615 & 0.641 & -20288 & 40615 & 0.64 & -20290 & 40617 \\
GNS & 0.644 & -20251 & 40542 & 0.644 & -20251 & 40541 & 0.644 & -20252 & 40544 \\
\hline
\end{tabular}

Table 5: Goodness of fit of the different model specifications for the agricultural land use share model

\subsection{Elasticities}

Interpretation of the parameter estimates (reported in the supplementary material) is complicated by both the log-odds transformation of the dependent variables and the nonlinear specification of land use shares. To deal with these complexities, we calculate the elasticities of agricultural land shares with respect to the agricultural rents based on equation 4. The calculated elasticities give the percentage change in the agricultural share which would result from a 1 percent change in the agricultural land proxy all other explanatory variables held constant. Appendix C provides more details on the calculus of these elasticities.

\footnotetext{
${ }^{20}$ This and the following figures are available in the supplementary materials (Appendix D), tables D2-D25.
} 


$$
\frac{\partial s_{a g}}{\partial \text { Agr rent }} * \frac{\text { Agr rent }}{s_{a g}}=\text { Total impact } \text { agr_rent }_{\text {re }} * \text { Agr rent }
$$

where, the total impact of the agricultural rent is the sum of the direct effects and indirect effects associated to the agricultural rent proxy. These direct and indirect effects are calculated for different spatial specifications as in Halleck Vega and Elhorst (2015).

The elasticity estimates are reported in table 6 . The results show that the elasticities of agricultural land use with respect to the shadow price are similar for the OLS, SLX, SDM, SDEM, and GNS specifications. The figures are higher for the SEM and lower for the SAR and SAC. In the case of the land price proxy, the elasticities have the expected signs in the SEM, SAR, SAC, SDEM, and GNS. For farmers' revenue, they are positive only for the OLS and SLX. These results show that only the shadow price proxy provides stable and intuitive results since this rent always ahs a positive and significant impact on agricultural land use.

\begin{tabular}{lccc}
\hline Model & Shadow Price & Land Price & Farmers' Revenues \\
\hline OLS & 0.3105 & -0.0743 & 0.266 \\
& {$[0.0979 ; 0.5231]$} & {$[-0.1439 ;-0.0047]$} & {$[0.1406 ; 0.3914]$} \\
SEM & 0.5114 & 0.148 & -0.0828 \\
& {$[0.1613 ; 0.8615]$} & {$[0.0094 ; 0.2866]$} & {$[-0.1218 ;-0.0438]$} \\
SAR & 0.0817 & 0.2156 & -0.4302 \\
& {$[0.0257 ; 0.1377]$} & {$[0.0137 ; 0.4175]$} & {$[-0.633 ;-0.2274]$} \\
SDM & 0.1812 & -0.0749 & -0.0203 \\
& {$[0.0571 ; 0.3053]$} & {$[-0.145 ;-0.0048]$} & {$[-0.0299 ;-0.0107]$} \\
SAC & 0.0384 & 0.3248 & -0.5455 \\
& {$[0.0121 ; 0.0647]$} & {$[0.0206 ; 0.629]$} & {$[-0.8026 ;-0.2884]$} \\
SLX & 0.209 & -0.1529 & 0.2447 \\
& {$[0.0659 ; 0.3521]$} & {$[-0.2961 ;-0.0097]$} & {$[0.1294 ; 0.36]$} \\
SDEM & 0.2774 & 0.1278 & -0.0095 \\
& {$[0.0875 ; 0.4673]$} & {$[0.0081 ; 0.2475]$} & {$[-0.014 ;-0.005]$} \\
GNS & 0.3125 & 0.2849 & -0.1373 \\
& {$[0.0985 ; 0.5265]$} & {$[0.018 ; 0.5518]$} & {$[-0.202 ;-0.0726]$} \\
\hline
\end{tabular}

Table 6: Elasticities for the agricultural land use share model with respect to agricultural land rent proxies. 95\% confidence intervals in brackets. 


\subsection{Predictions}

There are generally three types of predictors for spatial econometric models. The first type is the fitted values obtained when the model is estimated and response variables are observed. The second type is based on a set of observations for which response variables are available but which are related to a set of individuals for whom the response variables are unknown (Thomas-Agnan, Laurent and Goulard, 2014; Kelejian and Prucha, 2007). In our comparison, we use the first type which is based on available information concerning the response variables.

In order to compare the quality of the prediction for the different spatial model specifications with different rent proxies we calculate the NRMSE as follows:

$$
\begin{gathered}
\mathrm{RMSE}_{k}=\sqrt{\frac{\sum_{i=1}^{n}\left(\hat{y}_{i k}-y_{i k}\right)^{2}}{n}} \\
\mathrm{NRMSE}_{k}=\frac{\mathrm{RMSE}}{y_{k}^{\text {max }}-y_{k}^{\text {min }}}
\end{gathered}
$$

Table 7 presents the values of the NRMSE for the three rent proxies, and the different spatial specifications for the agricultural land use share. Table 7 shows that accounting for spatial dependence is reducing the NRMSE when predicting agricultural land use, regardless of the proxy for the agricultural rent. According to our results, the GNS model seems to provide the most accurate prediction regardless of the agricultural rent proxy. Table B1 in the appendix provides the NRMSE scores for the other land use shares.

\begin{tabular}{lccc}
\hline Model & Shadow Price & Land Price & Farmers' Revenues \\
\hline OLS & 0.2340 & 0.2294 & 0.2348 \\
SEM & 0.1218 & 0.1204 & 0.1214 \\
SAR & 0.1269 & 0.1253 & 0.1264 \\
SDM & 0.1234 & 0.1222 & 0.1230 \\
SAC & 0.1288 & 0.1277 & 0.1285 \\
SLX & 0.2289 & 0.2240 & 0.2289 \\
SDEM & 0.1235 & 0.1222 & 0.1232 \\
GNS & 0.1190 & 0.1175 & 0.1185 \\
\hline
\end{tabular}

Table 7: Normalized root-mean-square error results for the agricultural land use models 

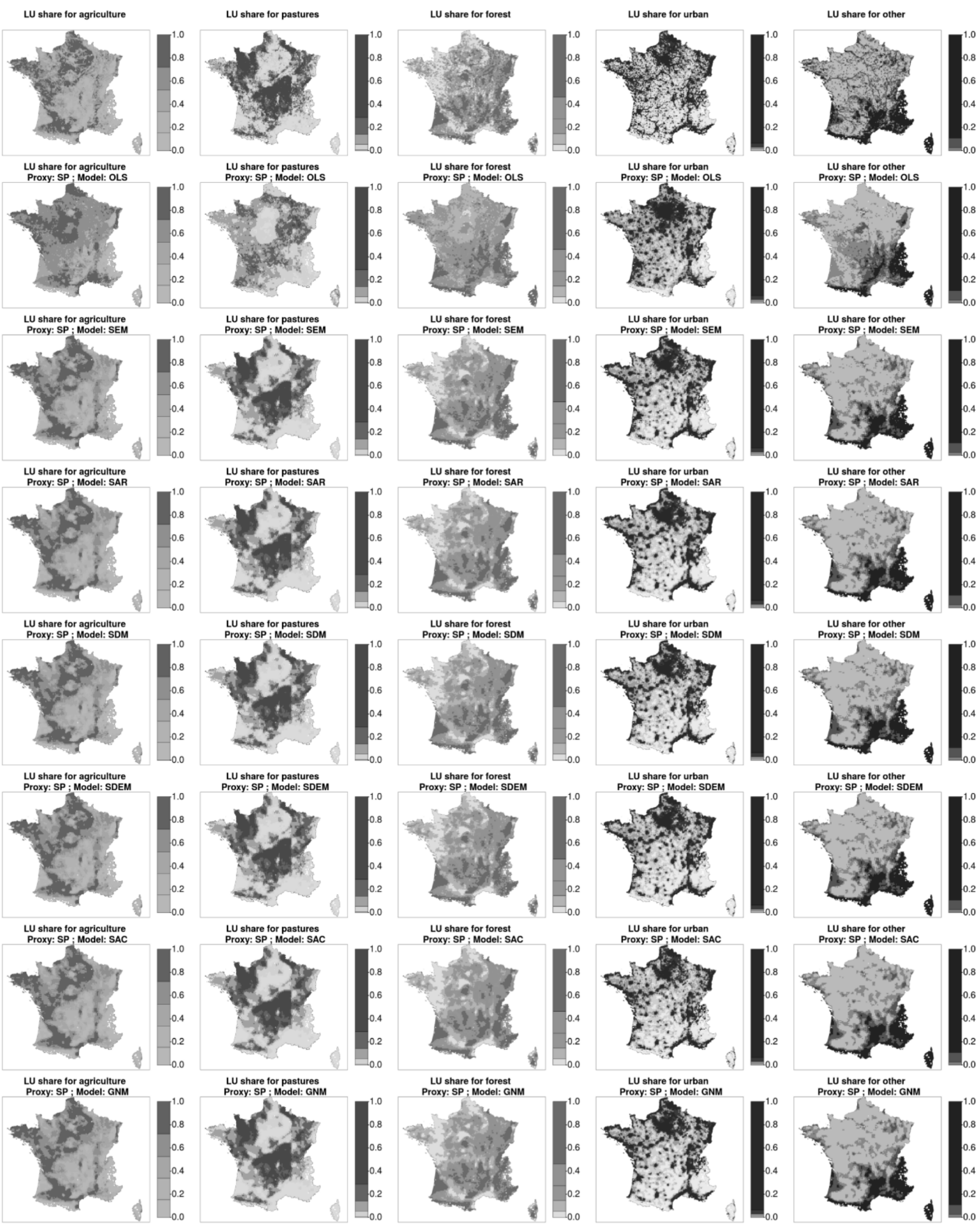

Figure 2: Observed land use shares (top row) and predicted. Proxy for the agricultural rent: shadow price; in-sample fit (dependent variables known) 


\section{Conclusion}

The objective of this paper was to compare land use models based on three different proxies for agricultural land rent - farmers' revenues, land prices, and shadow land prices - derived from a mathematical programming model. We estimated land use share models for France at a homogeneous ( $8 \mathrm{~km}$ x $8 \mathrm{~km})$ grid scale, and considered five land use classes: (1) agriculture, (2) pasture, (3) forest, (4) urban, and (5) other. We investigated what determines the shares of land in alternative uses using economic, physical, and demographic explanatory variables. We modeled spatial dependence between grid cells, and compared prediction accuracy and estimated elasticities for the different spatial model specifications (OLS, SLX, SEM, SAR, SDM, SDEM, SAC, GNS). We then compared these spatial specifications using the three rent proxies. These comparisons are based on several criteria: quality of economic explanation (significance of agricultural rents and their marginal impacts), prediction quality (NRMSE), specification tests (LM tests) and goodness of fit (LL, $R^{2}$, AIC).

The results of LM tests from the OLS, SEM, SAR, and SLX specifications show that the SDM, SDEM, SAC, and GNS models should be considered. According to the goodness of fit criteria (pseudo-R squared, log-likelihood, and AIC) and prediction quality criteria the GNS is the specification which best fits our data. In a context of aggregated land use, the existence of autocorrelation, is due mainly to the spatially correlated errors essentially a data measurement problem. This is true especially in our case since we use artificially constructed grids, and because of different scales for the explanatory variables and land use data.

Our results show also that including spatial dependence in land use share models improves the quality of the predictions (NRMSE indicators) which confirms previous results in the aggregated land use literature (Chakir and Le Gallo, 2013; Ay et al., 2016). Our results show also that prediction quality is similar for the three agricultural rent proxies. This might be explained by the fact that the three agricultural rent proxies are observed at very aggregated scales, and do not explain much of the total variation in land use shares.

Concerning the comparison between the different rent proxies, from the statistical 
point of view, they give the same results in terms of prediction accuracy (NRMSE) and goodness of fit of different spatial specifications. However, from an economic viewpoint the results show that only the shadow price proxy provides stable and intuitive results; it always has a positive and significant impact on agricultural land use.

Our model could be used to simulate climate change impacts on land use and to simulate the effects of mitigation policies. This would be useful for policy makers to provide insights into future LUC climate change scenarios, and to evaluate policy mechanisms designed to reduce the negative environmental externalities of LUC (greenhouse gas emissions, loss of biodiversity, reduced water quality, etc.).

Acknowledgments We would like to thank Professor Paul Elhorst for his very helpful advices as well as the anonymous reviewers for their valuable comments and suggestions which have greatly contributed to improve the manuscript. The authors would like to thank Pierre-Alain Jayet (Economie Publique, INRA) for providing the data on land shadow prices and Antonello Lobianco (LEF, INRA) for providing data on forest rents. We acknowledge funding from French National Research Agency (ANR) under the ORACLE project (ANR-10-CEPL-011) and the ModULand project (ANR-11-BSH1-005). Anna Lungarska expresses her gratitude to the INRA US ODR team for their hospitality. The usual disclaimers apply.

\section{References}

Ahn, S., Plantinga, A. J. and Alig, R. J. (2000). Predicting Future Forestland Area : Comparison of Econometric Approaches. Forest Science, 46(2384), 363-376.

Anselin, L. (1988). Spatial Econometrics : Methods and Models. Kluwer Academic Publishers, Dordrecht.

Anselin, L. (2007). Spatial econometrics in RSUE: Retrospect and prospect. Regional Science and Urban Economics, 37(4), 450-456.

Anselin, L., Bera, A. K., Florax, R. and Yoon, M. J. (1996). Simple diagnostic tests for spatial dependence. Regional Science and Urban Economics, 26(1), 77-104. 
Ay, J.-S., Chakir, R., Doyen, L., Jiguet, F. and Leadley, P. (2014). Integrated models, scenarios and dynamics of climate, land use and common birds. Climatic Change, 126(12), 13-30, doi:10.1007/s10584-014-1202-4.

Ay, J.-S., Chakir, R. and Le Gallo, J. (2016). Aggregated Versus Individual Land-Use Models: Modeling Spatial Autocorrelation to Increase Predictive Accuracy. Environmental Modeling \& Assessment, advance online publication, doi:10.1007/s10666-0169523-5.

Bivand, R., Hauke, J. and Kossowski, T. (2013). Computing the jacobian in gaussian spatial autoregressive models: An illustrated comparison of available methods. Geographical Analysis, 45(2), 150-179.

Bivand, R. and Piras, G. (2015). Comparing implementations of estimation methods for spatial econometrics. Journal of Statistical Software, 63(18), 1-36.

Brady, M. and Irwin, E. (2011). Accounting for spatial effects in economic models of land use: Recent developments and challenges ahead. Environmental $\mathscr{E}$ Resource Economics, 48(3), 487-509.

Brisson, N., Gary, C., Justes, E., Roche, R., Mary, B., Ripoche, D., Zimmer, D., Sierra, J., Bertuzzi, P., Burger, P., Bussière, F., Cabidoche, Y., Cellier, P., Debaeke, P., Gaudillère, J., Hénault, C., Maraux, F., Seguin, B. and Sinoquet, H. (2003). An overview of the crop model STICS. European Journal of Agronomy, 18(3-4), 309-332, doi:10.1016/S1161-0301(02)00110-7.

Brisson, N., Launay, M., Mary, B. and Beaudoin, N. (2009). Conceptual Basis, Formalisations and Parameterization of the STICS Crop Model. QUAE.

Carrion-Flores, C. and Irwin, E. G. (2004). Determinants of residential land-use conversion and sprawl at the rural-urban fringe. American Journal of Agricultural Economics, 86(4), 889-904.

Caurla, S. and Delacote, P. (2012). Ffsm : un modèle de la filière forêts-bois française qui prend en compte les enjeux forestiers dans la lutte contre le changement climatique. INRA Sciences Sociales, 4. 
Caurla, S., Delacote, P., Lecocq, F., Barthès, J. and Barkaoui, A. (2013). Combining an inter-sectoral carbon tax with sectoral mitigation policies: Impacts on the french forest sector. Journal of Forest Economics, 19(4), 450-461, doi:10.1016/j.jfe.2013.09.002.

Cavailhès, J. and Wavresky, P. (2003). Urban influences on periurban farmland prices. European Review of Agriculture Economics, 30(3), 333-357, doi:10.1093/erae/30.3.333.

Chakir, R. and Le Gallo, J. (2013). Predicting land use allocation in France: A spatial panel data analysis. Ecological Economics, 92(0), 114-125, doi:10.1016/j.ecolecon.2012.04.009.

Chakir, R. and Parent, O. (2009). Determinants of land use changes: A spatial multinomial probit approach. Papers in Regional Science, 88(2), 327-344.

Clark, J. S., Fulton, M. and Scott, J. T. (1993). The inconsistency of land values, land rents, and capitalization formulas. American Journal of Agricultural Economics, 75(1), $147-155$.

Corrado, L. and Fingleton, B. (2012). Where is the economics in spatial econometrics? Journal of Regional Science, 52(2), 210-239.

De Pinto, A. and Nelson, G. C. (2007). Modelling deforestation and land-use change: Sparse data environments. Journal of Agricultural Economics, 58(3), 502-516.

Dupraz, P. and Temesgen, C. (2012). Farmland Rental Rate and Marginal Return to Land: A French FADN Perspective. 86th Annual Conference, April 16-18, 2012, Warwick University, Coventry, UK 134954, Agricultural Economics Society.

Elhorst, J. P. (2010). Applied spatial econometrics: Raising the bar. Spatial Economic Analysis, 5(1), 9-28, doi:10.1080/17421770903541772.

Elhorst, J. P. (2014). Spatial econometrics: from cross-sectional data to spatial panels. Springer.

Ferdous, N. and Bhat, C. R. (2013). A spatial panel ordered-response model with application to the analysis of urban land-use development intensity patterns. Journal of Geographical Systems, 15(1), 1-29, doi:10.1007/s10109-012-0165-0. 
Fezzi, C. and Bateman, I. J. (2011). Structural agricultural land use modeling for spatial agro-environmental policy analysis. American Journal of Agricultural Economics, 93(4), 1168-1188, doi:10.1093/ajae/aar037.

Foley, J. A., DeFries, R., Asner, G. P., Barford, C., Bonan, G., Carpenter, S. R., Chapin, F. S., Coe, M. T., Daily, G. C., Gibbs, H. K., Helkowski, J. H., Holloway, T., Howard, E. A., Kucharik, C. J., Monfreda, C., Patz, J. A., Prentice, I. C., Ramankutty, N. and Snyder, P. K. (2005). Global consequences of land use. Science, 309(5734), 570-574, doi:10.1126/science.1111772.

Gibbons, S. and Overman, H. G. (2012). Mostly pointless spatial econometrics?*. Journal of Regional Science, 52(2), 172-191.

Guiling, P., Brorsen, B. W. and Doye, D. (2009). Effect of urban proximity on agricultural land values. Land Economics, 85(2), 252-264.

Gutierrez, L., Westerlund, J. and Erickson, K. (2007). Farmland prices, structural breaks and panel data. European Review of Agricultural Economics, 34(2), 161-179, doi:10.1093/erae/jbm018.

Haim, D., Alig, R. J., Plantinga, A. J. and Sohngen, B. (2011). Climate change and future land use in the united states: an economic approach. Climate Change Economics, 02(01), 27-51, doi:10.1142/S2010007811000218.

Halleck Vega, S. and Elhorst, J. P. (2015). The SLX model. Journal of Regional Science, 55(3), 339-363, doi:10.1111/jors.12188.

Hardie, I., Parks, P., Gottleib, P. and Wear, D. N. (2000). Responsiveness of rural and urban land uses to land rent determinants in the u.s. south. Land Economics, 76 (4), $659-673$.

Irwin, E. G., Bell, K. P. and Geoghegan, J. (2003). Modeling and managing urban growth at the rural-urban fringe: A parcel-level model of residential land use change. Agricultural and Resource Economics Review, 32(1), 83-102. 
Jayet, P.-A., Petsakos, A., Chakir, R., Lungarska, A., De Cara, S., Petel, E., Humblot, P., Godard, C., Leclère, D., Cantelaube, P., Bourgeois, C., Bamière, L., Ben Fradj, N., Aghajanzadeh-Darzi, P., Dumollard, G., Ancuta, I. and Adrian, J. (2015). The European agro-economic AROPAj model. Thiverval-Grignon: INRA, UMR Economie Publique, https://www6.versailles-grignon.inra.fr/economie_ publique_eng/Research-work.

Karlsson, J. and Nilsson, P. (2013). Capitalisation of Single Farm Payment on farm price: an analysis of Swedish farm prices using farm-level data. European Review of Agricultural Economics, 41(2), doi:10.1093/erae/jbt021.

Kelejian, H. H. and Prucha, I. R. (2007). The relative efficiencies of various predictors in spatial econometric models containing spatial lags. Regional Science and Urban Economics, 37(3), 363-374.

Leclère, D., Jayet, P.-A. and de Noblet-Ducoudré, N. (2013). Farm-level autonomous adaptation of european agricultural supply to climate change. Ecological Economics, 87(0), 1 - 14, doi:10.1016/j.ecolecon.2012.11.010.

LeSage, J. and Pace, R. K. (2009). Introduction to Spatial Econometrics. CRC Press, Boca Raton FL.

Li, M., Wu, J. and Deng, X. (2013). Identifying drivers of land use change in China: A spatial multinomial logit model analysis. Land Economics, 89(4), 632-654.

Lichtenberg, E. (1989). Land quality, irrigation development, and cropping patterns in the northern high plains. American Journal of Agricultural Economics, Vol. 71, No. 1, $187-194$.

Lobianco, A., Delacote, P., Caurla, S. and Barkaoui, A. (2015). The importance of introducing spatial heterogeneity in bio-economic forest models: Insights gleaned from FFSM++. Ecological Modelling, 309-310, 82-92, doi:10.1016/j.ecolmodel.2015.04.012.

Lobianco, A., Delacote, P., Caurla, S. and Barkaoui, A. (2016). Accounting for active management and risk attitude in forest sector models. Environmental Modeling \& Assessment, 21, 391-405, doi:10.1007/s10666-015-9483-1. 
Lubowski, R., Plantinga, A. and Stavins, R. (2008). What Drives Land-Use Change in the United States? A National Analysis of Landowner Decisions. Land Econmics, 84(4), $551-572$.

McFadden, D. (1978). Cost, revenue, and profit functions. In M. Fuss and D. McFadden (eds.) Production Economics: A Dual Approach to Theory and Applications, volume 1 of History of Economic Thought Chapters, chapter 1. McMaster University Archive for the History of Economic Thought.

Mendelsohn, R., Nordhaus, W. D. and Shaw, D. (1994). The Impact of Global Warming on Agriculture: A Ricardian Analysis. The American Economic Review, 84, 753-771.

Miller, D. J. and Plantinga, A. J. (1999). Modeling land use decisions with aggregate data. American Journal of Agricultural Economics, 81(1), 180-194.

Moran, P. (1948). The interpretation of statistical maps. Journal of the Royal Statistical Society, 10B, 243-251.

Nagelkerke, N. J. D. (1991). A note on a general definition of the coefficient of determination. Biometrika, 78(3), 691-692, doi:10.1093/biomet/78.3.691.

Panagos, P., Van Liedekerke, M., Jones, A. and Montanarella, L. (2012). European Soil Data Centre: Response to European policy support and public data requirements. Land Use Policy, 29(2), 329-338, doi:10.1016/j.landusepol.2011.07.003.

Plantinga, A., Mauldin, T. and Miller, D. (1999). An econometric analysis of the costs of sequestering carbon in forests. American Journal of Agricultural Economics, 81, 812-24.

Plantinga, A. J. (1996). The effect of agricultural policies on land use and environmental quality. American Journal of Agricultural Economics, 78(4), 1082-1091.

Plantinga, A. J. and Ahn, S. (2002). Efficient policies for environmental protection: An econometric analysis of incentives for land conversion and retention. Journal of Agricultural and Resource Economics, 27(1), 128-145.

Randall, A. and Castle, E. N. (1985). Land resources and land markets. In A. V. Kneese and J. L. Sweeney (eds.) Handbook of Natural Resource and Energy Economics, volume 2 
of Handbook of Natural Resource and Energy Economics, chapter 13, (pp. 571-620). Elsevier.

Rhemtulla, J. M., Mladenoff, D. J. and Clayton, M. K. (2009). Historical forest baselines reveal potential for continued carbon sequestration. Proceedings of the National Academy of Sciences USA, 106, 6082-6087.

Ricardo, D. (1817). The principles of political economy and taxation. London: John Murray, Albemarle-street.

Sala, O. E., Stuart Chapin, F. I., Armesto, J. J., Berlow, E., Bloomfield, J., Dirzo, R., Huber-Sanwald, E., Huenneke, L. F., Jackson, R. B., Kinzig, A., Leemans, R., Lodge, D. M., Mooney, H. A., Oesterheld, M., Poff, N. L., Sykes, M. T., Walker, B. H., Walker, M. and Wall, D. H. (2000). Global biodiversity scenarios for the year 2100. Science, 287(5459), 1770-1774, doi:10.1126/science.287.5459.1770.

Schlenker, W., Michael Hanemann, W. and Fisher, A. C. (2005). Will U.S. Agriculture Really Benefit from Global Warming? Accounting for Irrigation in the Hedonic Approach. American Economic Review, 95(1), 395-406, doi:10.1257/0002828053828455.

Schröter, D., Cramer, W., Leemans, R., Prentice, I. C., Araújo, M. B., Arnell, N. W., Bondeau, A., Bugmann, H., Carter, T. R., Gracia, C. A., de la Vega-Leinert, A. C., Erhard, M., Ewert, F., Glendining, M., House, J. I., Kankaanpää, S., Klein, R. J. T., Lavorel, S., Lindner, M., Metzger, M. J., Meyer, J., Mitchell, T. D., Reginster, I., Rounsevell, M., Sabaté, S., Sitch, S., Smith, B., Smith, J., Smith, P., Sykes, M. T., Thonicke, K., Thuiller, W., Tuck, G., Zaehle, S. and Zierl, B. (2005). Ecosystem service supply and vulnerability to global change in europe. Science, 310(5752), 1333-1337, doi:10.1126/science.1115233.

Sidharthan, R. and Bhat, C. R. (2012). Incorporating spatial dynamics and temporal dependency in land use change models. Geographical Analysis, 44(4), 321-349, doi:10.1111/j.1538-4632.2012.00854.x.

Stavins, R. N. and Jaffe, A. B. (1990). Unintended impacts of public investments on pri- 
vate decisions: The depletion of forested wetlands. American Economic Review, 80(3), $337-352$.

Stevenson, R. J. and Sabater, S. (2010). Understanding effects of global change on river ecosystems: science to support policy in a changing world. Hydrobiologia, 657, 3-18.

Thomas-Agnan, C., Laurent, T. and Goulard, M. (2014). About predictions in spatial autoregressive models: Optimal and almost optimal strategies.

von Thünen, J. H. (1826). Der Isolierte Staat. Beziehung auf Landwirtschaft und Nationalökonomie.

Wu, J. and Segerson, K. (1995). The impact of policies and land characteristics on potential groundwater pollution in wisconsin. American Journal of Agricultural Economics, $77(4), 1033-1047$.

Zellner, A. and Lee, T. (1965). Joint estimation of relationships involving discrete random variables. Econometrica, 33, 382-94. 


\section{A Data}

\begin{tabular}{lrr}
\hline Land Cover class & CLC value & LU class \\
\hline 1 Artificial Surfaces & $1, \ldots, 11$ & Urban \\
2 Agricultural Areas & $12, \ldots, 17$ & Agriculture \\
& and $19, \ldots, 22$ & \\
2.3 Pastures & 18 & Pastures \\
3 Forest and Semi Natural Areas & 23,24 and 25 & Forest \\
3.2.1 Natural grasslands & 26 & Other \\
3.2.2 Moors and heathland & 27 & Other \\
3.2.3 Sclerophyllous vegetation & 28 & Other \\
3.2.4 Transitional woodland-shrub & 29 & Other \\
3.3 Open spaces with little or no vegetation & $30, \ldots, 34$ & Other \\
4 Wetlands & $35, \ldots, 39$ & Other \\
5 Water bodies & $40, \ldots, 44$ & Other \\
\hline
\end{tabular}

Table A1: Extract from the CLC classification and the corresponding LU aggregation

\begin{tabular}{lrr}
\hline Agricultural activity & $\begin{array}{r}\text { Profit before tax } \\
(1000 \text { euros })\end{array}$ & $\begin{array}{r}\text { Average farm surface } \\
\text { (ha) }\end{array}$ \\
\hline Cereals and protein crops & 24.1 & 68 \\
Horticulture & 30.7 & 7 \\
Wine under geographical label & 52,9 & $12^{*}$ \\
Other wine & 13.1 & $12^{*}$ \\
Fruits and others & 10.5 & 13 \\
Bovine (milk) & 28.8 & 58 \\
Bovine (meat) & 24.2 & 46 \\
Bovine (mixed) & 33.1 & 75 \\
Sheep and other & 17.6 & 25 \\
Pig, poultry and other & 36.6 & 34 \\
Mixed farming & 27.0 & 48 \\
\hline
\end{tabular}

* Average for viticulture in general

Table A2: Average farmers' profits for 2005 per agricultural activity. The data on farms' size in hectares is for 2000. Source: Agreste, French Ministry of agriculture 


\section{B Predictions and NRMSE}

The fitted values are obtained by exploiting the $R$ package spdep. The estimates use the available response variables (the equations are presented in table 1), and the fitted values are calculated as the difference between the residuals and the model response variables. For more details, see the documentation accompanying $\mathrm{R}$ package spdep.

Table B1 provides the scores for the in-sample fit if the dependent variables are known.

\begin{tabular}{rrrrrr}
\hline & s_ot & S_ag & s_pa & s_fo & s_ur \\
\hline Shadow Price & & & & & \\
OLS & 0.1211 & 0.2340 & 0.1882 & 0.1882 & 0.0676 \\
SEM & 0.0778 & 0.1218 & 0.0772 & 0.1141 & 0.0545 \\
SAR & 0.0766 & 0.1269 & 0.0779 & 0.1176 & 0.0544 \\
SDM & 0.0767 & 0.1234 & 0.0769 & 0.1139 & 0.0539 \\
SAC & 0.0741 & 0.1288 & 0.0744 & 0.1129 & 0.0583 \\
SLX & 0.1197 & 0.2289 & 0.1860 & 0.1822 & 0.0675 \\
SDEM & 0.0772 & 0.1235 & 0.0776 & 0.1137 & 0.0531 \\
GNS & 0.0741 & 0.1190 & 0.0736 & 0.1093 & 0.0515
\end{tabular}

Land price

$\begin{array}{rlllll}\text { OLS } & 0.1230 & 0.2294 & 0.1850 & 0.1865 & 0.0667 \\ \text { SEM } & 0.0781 & 0.1204 & 0.0768 & 0.1135 & 0.0546 \\ \text { SAR } & 0.0770 & 0.1253 & 0.0779 & 0.1166 & 0.0542 \\ \text { SDM } & 0.0768 & 0.1222 & 0.0769 & 0.1133 & 0.0543 \\ \text { SAC } & 0.0744 & 0.1277 & 0.0745 & 0.1120 & 0.0596 \\ \text { SLX } & 0.1213 & 0.2240 & 0.1834 & 0.1805 & 0.0673 \\ \text { SDEM } & 0.0774 & 0.1222 & 0.0772 & 0.1130 & 0.0533 \\ \text { GNS } & 0.0743 & 0.1175 & 0.0729 & 0.1086 & 0.0520\end{array}$

Farmers' Revenues

\begin{tabular}{rlllll} 
OLS & 0.1248 & 0.2348 & 0.1942 & 0.1921 & 0.0660 \\
SEM & 0.0781 & 0.1214 & 0.0775 & 0.1144 & 0.0544 \\
SAR & 0.0769 & 0.1264 & 0.0783 & 0.1177 & 0.0543 \\
SDM & 0.0771 & 0.1230 & 0.0775 & 0.1140 & 0.0540 \\
SAC & 0.0742 & 0.1285 & 0.0746 & 0.1126 & 0.0583 \\
SLX & 0.1241 & 0.2289 & 0.1917 & 0.1854 & 0.0663 \\
SDEM & 0.0775 & 0.1232 & 0.0781 & 0.1139 & 0.0531 \\
GNS & 0.0739 & 0.1185 & 0.0745 & 0.1093 & 0.0517 \\
\hline
\end{tabular}

Table B1: In-sample estimation fit 


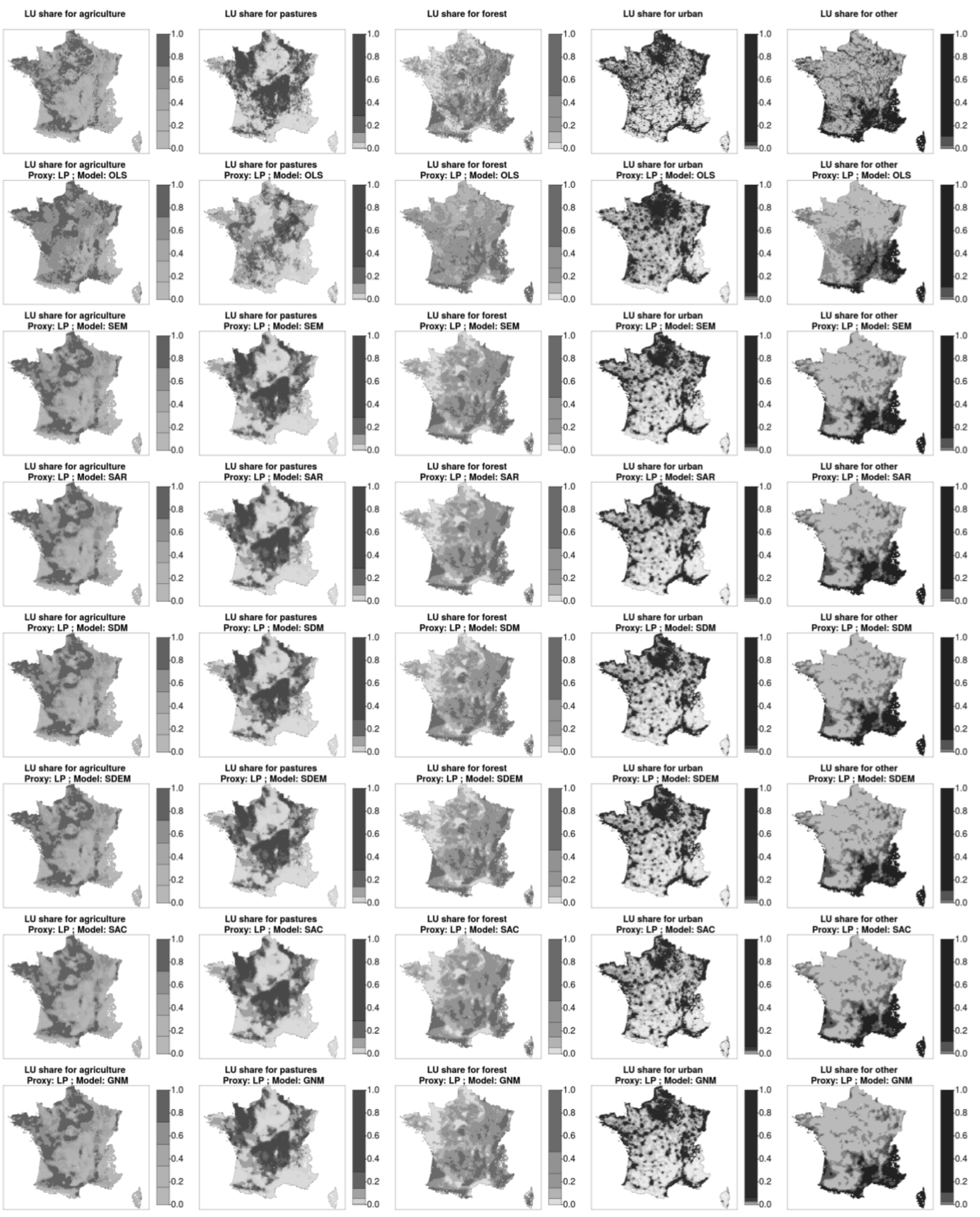

Figure B1: Observed land use shares (top row) and predicted. Proxy for the agricultural rent: land price; in-sample fit (dependent variables known) 

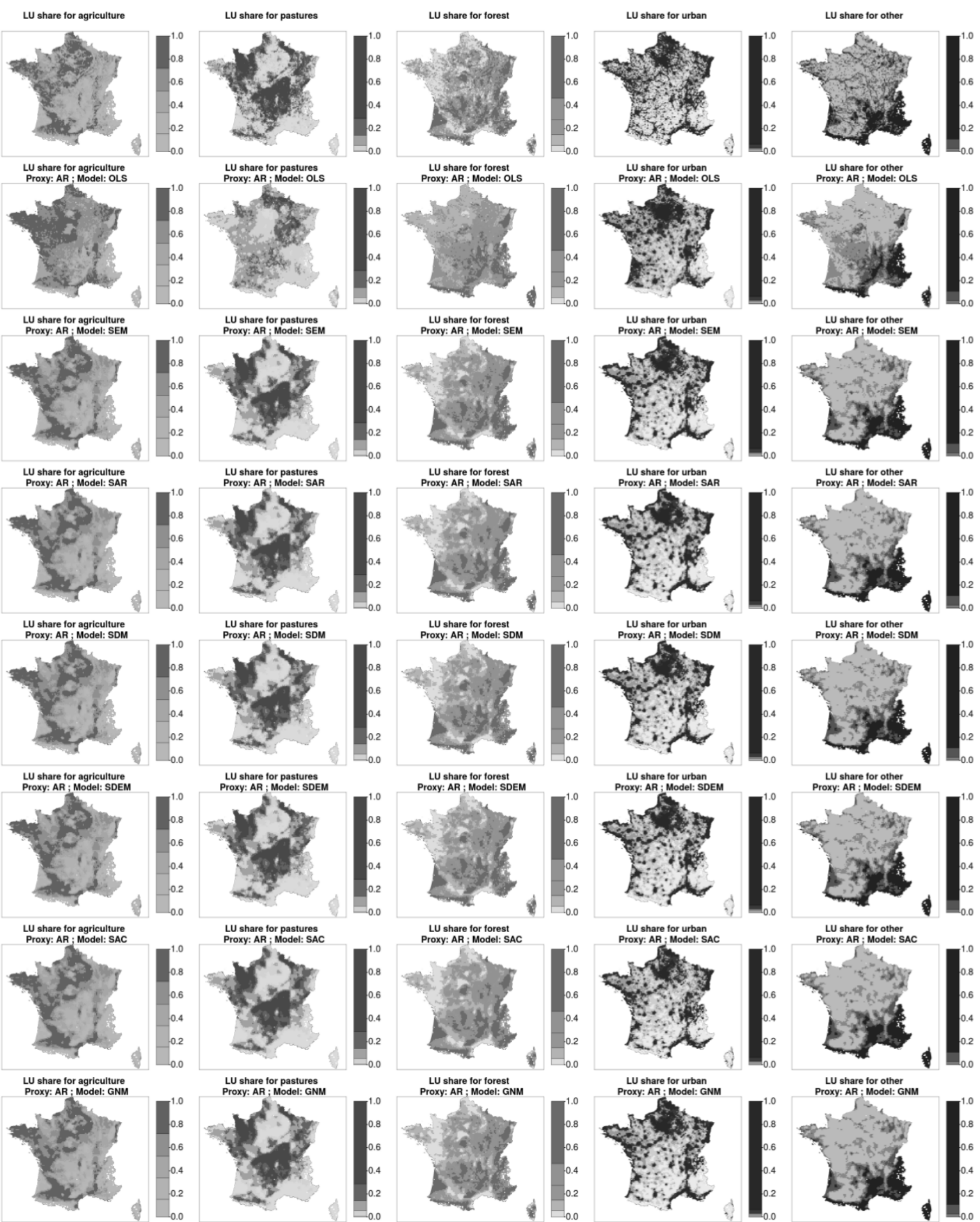

Figure B2: Observed land use shares (top row) and predicted. Proxy for the agricultural rent: farmers' revenues; in-sample fit (dependent variables known) 


\section{Elasticities}

Calculus for the elasticities.

$$
\begin{aligned}
& \frac{\partial \ln \left(\frac{s_{a g}}{s_{o t}}\right)}{\partial A g r \text { rent }}=\text { Total effect } \text { agr_rent } \\
& \frac{\partial\left(\frac{s_{a g}}{s_{o t}}\right)}{\partial A g r \text { rent }} * \frac{s_{o t}}{s_{a g}}=\text { Total effect } \text { agr_rent } \\
& \frac{\partial s_{a g}}{\partial A g r \text { rent }} * \frac{1}{s_{o t}} * \frac{s_{o t}}{s_{a g}}=\text { Total } \text { effect }_{\text {agr_rent }} \\
& \frac{\partial s_{a g}}{\partial A g r \text { rent }}=s_{a g} * \text { Total effect } \text { agr_rent } \\
& \frac{\partial s_{a g}}{\partial A g r \text { rent }} * \frac{\text { Agr rent }}{s_{a g}}=s_{a g} * \text { Total effect } \text { agr_rent } * \frac{\text { Agr rent }}{s_{a g}} \\
& \frac{\partial s_{a g}}{\partial A g r \text { rent }} * \frac{\text { Agr rent }}{s_{a g}}=\text { Total } \text { effect }_{\text {agr_rent }} * \text { Agr rent }
\end{aligned}
$$

The total effect of the agricultural rent is the sum of the direct and indirect effects (spillovers from neighbors). These direct and indirect effects are calculated as in Halleck Vega and Elhorst (2015). 


\begin{tabular}{|c|c|c|c|c|c|c|c|c|}
\hline Agr rent & Model & Min. & 1st $\mathrm{Qu}$. & Median & Mean & 3rd Qu. & Max & St.Dev \\
\hline \multirow{8}{*}{ Shadow price } & OLS & 0 & 0.235 & 0.264 & 0.31 & 0.367 & 0.555 & 0.106 \\
\hline & SLX & 0 & 0.158 & 0.178 & 0.209 & 0.247 & 0.374 & 0.072 \\
\hline & SEM & 0.001 & 0.387 & 0.435 & 0.511 & 0.605 & 0.914 & 0.175 \\
\hline & SAR & 0 & 0.062 & 0.07 & 0.082 & 0.097 & 0.146 & 0.028 \\
\hline & SDM & 0 & 0.137 & 0.154 & 0.181 & 0.214 & 0.324 & 0.062 \\
\hline & SDEM & 0 & 0.21 & 0.236 & 0.277 & 0.328 & 0.496 & 0.095 \\
\hline & $\mathrm{SAC}$ & 0 & 0.029 & 0.033 & 0.038 & 0.045 & 0.069 & 0.013 \\
\hline & GNS & 0 & 0.236 & 0.266 & 0.312 & 0.37 & 0.559 & 0.107 \\
\hline \multirow{8}{*}{ Land price } & OLS & -0.441 & -0.09 & -0.068 & -0.074 & -0.052 & 0 & 0.035 \\
\hline & SLX & -0.907 & -0.186 & -0.139 & -0.153 & -0.108 & 0 & 0.072 \\
\hline & SEM & 0 & 0.104 & 0.134 & 0.148 & 0.18 & 0.878 & 0.069 \\
\hline & SAR & 0 & 0.152 & 0.196 & 0.216 & 0.262 & 1.279 & 0.101 \\
\hline & $\mathrm{SDM}$ & -0.444 & -0.091 & -0.068 & -0.075 & -0.053 & 0 & 0.035 \\
\hline & SDEM & 0 & 0.09 & 0.116 & 0.128 & 0.155 & 0.758 & 0.06 \\
\hline & SAC & 0 & 0.229 & 0.295 & 0.325 & 0.395 & 1.927 & 0.152 \\
\hline & GNS & 0 & 0.201 & 0.259 & 0.285 & 0.346 & 1.691 & 0.133 \\
\hline \multirow{8}{*}{ Farmers' revenues } & OLS & 0.078 & 0.229 & 0.251 & 0.266 & 0.31 & 0.399 & 0.063 \\
\hline & SLX & 0.072 & 0.211 & 0.231 & 0.245 & 0.285 & 0.367 & 0.058 \\
\hline & SEM & -0.124 & -0.096 & -0.078 & -0.083 & -0.071 & -0.024 & 0.02 \\
\hline & SAR & -0.645 & -0.501 & -0.406 & -0.43 & -0.37 & -0.126 & 0.101 \\
\hline & SDM & -0.03 & -0.024 & -0.019 & -0.02 & -0.017 & -0.006 & 0.005 \\
\hline & SDEM & -0.014 & -0.011 & -0.009 & -0.01 & -0.008 & -0.003 & 0.002 \\
\hline & $\mathrm{SAC}$ & -0.818 & -0.635 & -0.515 & -0.546 & -0.47 & -0.16 & 0.129 \\
\hline & GNS & -0.206 & -0.16 & -0.13 & -0.137 & -0.118 & -0.04 & 0.032 \\
\hline
\end{tabular}

Table C1: Elasticities of agricultural land with respect to different agricultural rent proxies 